\title{
Characterization of Asphalt Concrete Produced from Scrapped Tire Rubber
}

\author{
Gito Sugiyanto \\ Civil Engineering Department, Faculty of Engineering, Jenderal Soedirman University Purwokerto, \\ Mayjend Sungkono Street km.5, Blater, Kalimanah, Purbalingga, Central Java 53371, Indonesia \\ E-mail: gito_98@yahoo.com
}

\begin{abstract}
Scrapped tire rubbers have been proposed as flexible pavement components because they are waste materials. Sustainable development of flexible pavement by utilizing waste tire rubber to replace natural resources generates positive impact to the nature and reducing environmental pollution. This paper presents a study on the investigation of waste scrapped tire rubber as fine aggregate in the production of Asphalt Concrete (AC) mixture. There are three type of AC mixture with $0 \%, 50 \%$, and $100 \%$ of waste scrapped tire rubber replacement of aggregate at fraction No. $50(0.279 \mathrm{~mm})$. Laboratory test is performed on six characteristics of Marshall test are void in mineral aggregate, void in mixture, voids filled with bitumen, stability, flow, and Marshall quotient. The results showed that the optimum asphalt content for $\mathrm{AC}_{\text {Standard }}$ mixture is $6.78 \%$, while $\mathrm{AC}_{\text {Scrapped-tire }} 50 \%$ mixture is $7.10 \%$ and $\mathrm{AC}_{\text {Scrapped-tire } 100 \%}$ mixture is $6.22 \%$. Based on the Marshall Test characteristics, scrapped tire rubber can be used as an alternative material to replace fine aggregate in AC mixtures for road surface layer. The use of scrapped tire rubber in asphalt concrete mixtures can improve the resistance to permanent deformation due to ruts and provide better resistance to high temperatures and loads.
\end{abstract}

Keywords: Scrapped tire rubber, asphalt concrete mixture, Marshall test, stability, flow.

ENGINEERING JOURNAL Volume 21 Issue 4

Received 20 September 2016

Accepted 10 January 2017

Published 31 July 2017

Online at http://www.engj.org/

DOI:10.4186/ej.2017.21.4.193 


\section{Introduction}

The awareness to reuse or recycle waste materials such as scrapped tire rubber has been implemented in flexible pavement construction. The utilization of waste scrapped tire rubber is one of the alternatives for reducing environmental pollution and supporting Clean Development Mechanism (CDM) program. CDM is regarded as one of the most important internationally implemented market-based mechanisms to reduce carbon emissions [1]. Sustainable development of flexible pavement by utilizing waste to replace natural resources generates positive impact to the nature especially for non-biodegradable waste such as waste tire rubber [2]. Waste tire rubber was categorized as non-biodegradable waste because tire was design to have high durability to weathering and heat. Hence, it offers a lot of potential to be recycled or reused [3]. Endof-life tires have become a voluminous problem in many countries, stockpiles tires in Japan 1,000,000 tons and 3,750,000 in United States that need to be taken care of in order to reduce the risk of fire and environmental concern from leachate in stockpiles [4]. More than 273 million scrap tires are produced in United States each year [5] and more than 600,000 tons of waste tires were thrown out every year in Germany [6]. Stockpiled tires are dangerous not only from potential environmental threat but also from fire hazards and habitat for pests, such as mosquitoes $[7,8]$.

Among the waste treatment procedures for used tires, grinding is the most important method for converting the waste rubber into ground material [9]. The technology with much different evidence of success demonstrated by roads built in the last 40 years is the rubberized asphalt mixture obtained through the "wet process" which involves the utilization of the Recycled Tire Rubber Modified Bitumen's (RTR-MBs). Since 1960s, asphalt mixtures produced with RTR-MBs have been used in different parts of the world as solutions for different quality problems and, despite some downsides; in the majority of the cases they have demonstrated to enhance performance of road's pavement [10]. In Civil Engineering, waste tires are used in stabilizing embankments and as asphalt component [11-13]. Thousands of projects around in the world have shown the success of the latter. Several studies have examined the performance of asphalt mixtures that use crumb rubbers sourced from waste tires. These studies found that modified hot asphalt mixtures have excellent structures and increase the life span of a road surface, while decreasing maintenance costs, reflective cracking, and noise levels $[7,14]$. The use of rubberized bituminous mixtures produced by means of the socalled wet technology leads to significant benefits in comparison with standard paving solutions. This was proven by the reduction of both considered environmental indicators, ranging between $36 \%$ and $45 \%$ [15]. The use of scrapped tires grater is suitable for use in hot climates [16]. The addition of $2 \%$ and $5 \%$ latex grated old tires on asphalt can prevent cracked, bleeding, and minimize the release of grains on the surface of flexible pavements [16].

The aim of this study is to investigate the characteristics of asphalt concrete mixture produced from waste scrapped tire rubber as fine aggregate. The laboratory test is performed on six characteristics of Marshall test are void in mineral aggregate, void in mixture, voids filled with bitumen, stability, flow, and Marshall quotient can be used as indicator to determinate the optimum bitumen content of asphalt concrete mixture. Therefore, this study will contribute a significant impact for the future investigation in flexible pavement construction.

\section{Experimental Study}

\subsection{Asphalt Concrete and Gradation}

Asphalt concrete is a construction layer consisting of mixture of asphalt and continuously graded aggregate, mixed, spread, and compacted at a specific temperature. Layers of asphalt concrete consists of mixture of three types namely Asphalt Concrete-Wearing Course (AC-WC), Asphalt Concrete-Binder Course (AC-BC), and Asphalt Concrete Base (AC-Base) with maximum aggregate size of $19 \mathrm{~mm}, 25.4 \mathrm{~mm}$, and $37.5 \mathrm{~mm}$ respectively [17]. In this study, the aggregate gradations limit specification followed by Bina Marga SKBI 2.426.1987 [18]. Asphalt concrete mixture uses the middle of gradation at no. IV in Bina Marga SKBI Specification is shown in Table 1. 
Table 1. Aggregate gradation limits specification at no. IV Bina Marga SKBI 2.4-26.1987 [18].

\begin{tabular}{|c|c|c|c|}
\hline \multirow{2}{*}{$\begin{array}{l}\text { Sieve } \\
\text { number }\end{array}$} & \multirow{2}{*}{$\begin{array}{l}\text { Sieve size } \\
(\mathrm{mm})\end{array}$} & \multicolumn{2}{|c|}{ Percentage passing of the sieve $(\%)$} \\
\hline & & Lower limit & Upper limit \\
\hline 1 inch & 25.4 & - & - \\
\hline $3 / 4$ inch & 19.1 & - & 100 \\
\hline $1 / 2$ inch & 12.7 & 80 & 100 \\
\hline $3 / 8$ inch & 9.52 & 70 & 90 \\
\hline No. 4 & 4.76 & 50 & 70 \\
\hline No. 8 & 2.38 & 35 & 50 \\
\hline No. 30 & 0.59 & 18 & 29 \\
\hline No. 50 & 0.279 & 13 & 23 \\
\hline No. 100 & 0.149 & 8 & 16 \\
\hline No. 200 & 0.074 & 4 & 10 \\
\hline
\end{tabular}

\subsection{Material}

Materials that used in this study consist of coarse aggregate, fine aggregate, stone ash (as filler), scrapped tire rubber, and bitumen pen 60-70 from PERTAMINA. The scrapped tire rubber is obtained from retread tires in Purwokerto, Banyumas, Central Java, Indonesia. The materials used in this study, are shown in Fig. 1 through Fig. 5.

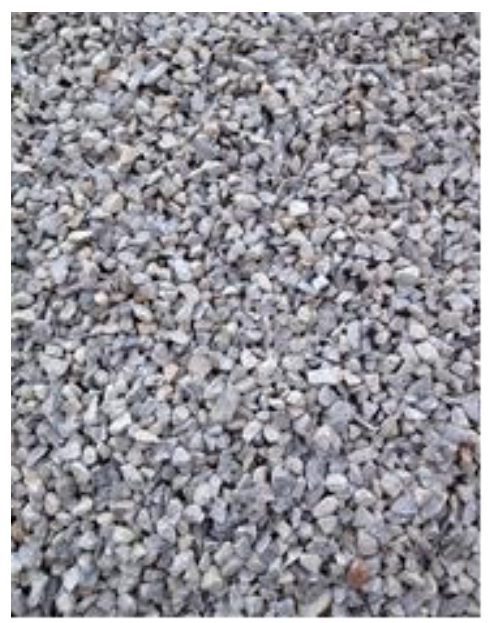

Fig. 1. Coarse aggregate.

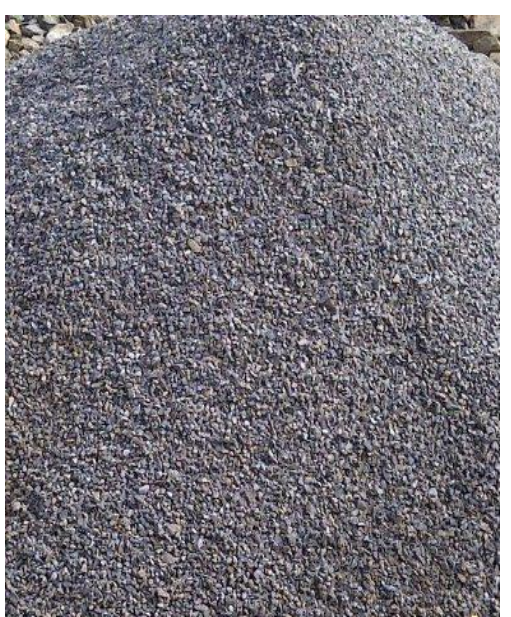

Fig. 2. Fine aggregate.

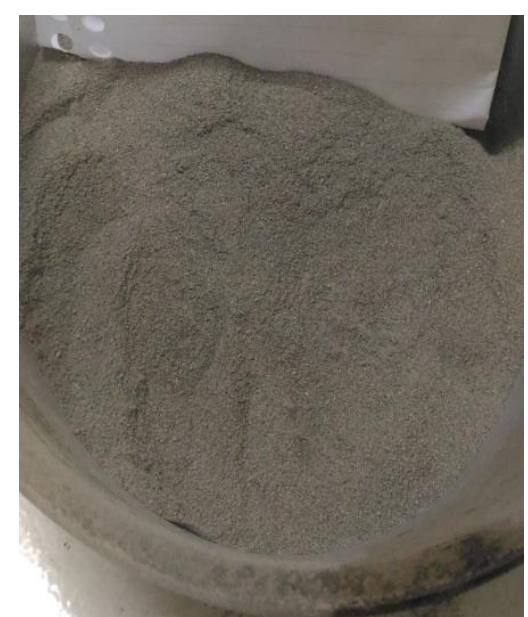

Fig. 3. Stone ash filler.

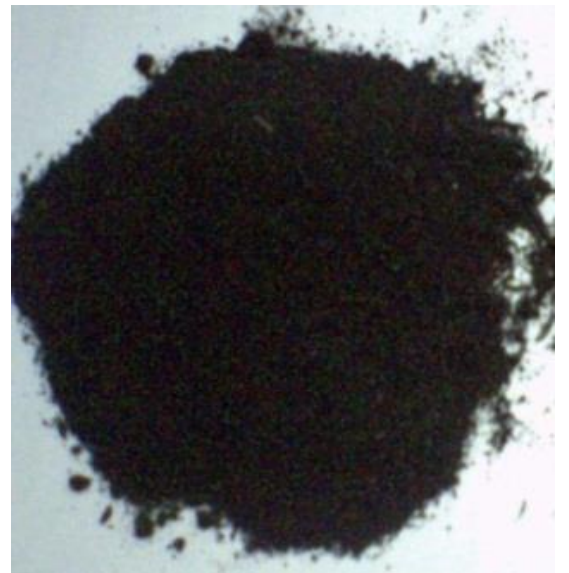

Fig. 4. Scrapped tire rubber.

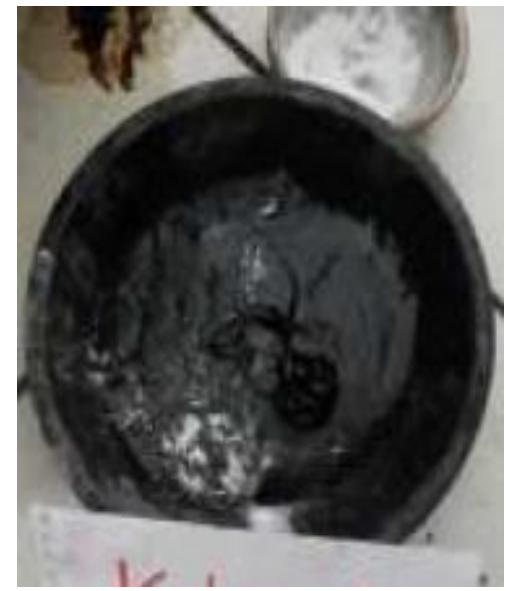

Fig. 5. Bitumen Pen 60/70. 


\subsection{Methods}

The method used in this study is an experimental testing in the laboratory. The conducted tests are specific gravity, absorption of water, abrasion with Los Angeles machine, adhesive of aggregate and asphalt, index of thinness on coarse aggregate. Specific gravity test for fine aggregate, filler, and scrapped tire rubber, asphalt test, Marshall test, and Marshall Immersion test. The standards used, are namely the Standard National of Indonesia (SNI) SNI 1969:2008 [19] for bulk specific gravity and water absorption test, SNI 2417:2008 [20] for abrasion with Los Angeles machine, SNI 03-2439-1991 [21] for adhesive of aggregate and asphalt, SNI06-2441-1991 [22] for specific gravity of asphalt test, SNI 06-2456-1991 [23] for penetration test, and SNI 06-2433-1991 [24] for flash point and fire point of asphalt. Asphalt content range from 6\% to $8 \%$ based on the research of Sugiyanto [25].

Asphalt concrete mixture is designed with absolute density approach in accordance to the design guidelines of Directorate General of Highways, Ministry of Public Works Republic of Indonesia [26]. There are three asphalt concrete $(\mathrm{AC})$ mixture type in this study: $\mathrm{AC}_{\text {Standard }}$ mixture, $\mathrm{AC}_{\text {scrapped-tire } 50 \%}$ mixture, and $\mathrm{AC}_{\text {Scrapped-tire } 100 \%}$ mixture.

a. AC $\mathrm{C}_{\text {tandard }}$ is mixture with the aggregate gradation limits specification at no. IV Bina Marga SKBI 2.426.1987 or mixture without scrapped tire rubber at fraction of No. $50(0.279 \mathrm{~mm})$.

b. AC $\mathrm{C}_{\text {scrapped-tire } 50 \%}$ is mixture with the aggregate gradation limits specification at no. IV Bina Marga SKBI 2.4-26.1987 that containing 50\% substitution of aggregate at fraction of No. $50(0.279 \mathrm{~mm})$ with scrapped tire rubber.

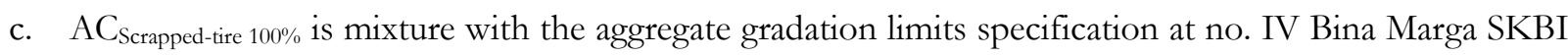
2.4-26.1987 that containing 100\% substitution of aggregate at fraction of No. $50(0.279 \mathrm{~mm})$ with scrapped tire rubber.

The total numbers of samples are 57, 45 samples for Stage 1: Marshall Test and 12 samples for Stage 2: Marshall Immersion test. For stage 1, number of samples of each mixture type is 15. Details of tests and number of samples of each stage are shown in Table 2.

Table 2. Number of samples in stage 1 and stage 2.

\begin{tabular}{|c|c|c|c|c|c|}
\hline \multirow[t]{2}{*}{ Stage } & \multirow[t]{2}{*}{ Test } & \multirow[t]{2}{*}{ Mixture type } & \multirow{2}{*}{$\begin{array}{l}\text { Asphalt } \\
\text { content } \\
(\%)\end{array}$} & \multicolumn{2}{|c|}{$\begin{array}{l}\text { Number } \\
\text { of samples }\end{array}$} \\
\hline & & & & Number & Total \\
\hline \multirow[t]{16}{*}{1.} & \multirow{15}{*}{$\begin{array}{l}\text { Marshall } \\
\text { Test }\end{array}$} & \multirow[t]{5}{*}{$\mathrm{AC}_{\text {Standard }}$} & 6.0 & 3 & \multirow[t]{5}{*}{15} \\
\hline & & & 6.5 & 3 & \\
\hline & & & 7.0 & 3 & \\
\hline & & & 7.5 & 3 & \\
\hline & & & 8.0 & 3 & \\
\hline & & \multirow[t]{5}{*}{$\mathrm{AC}_{\text {Scrapped-tire } 50 \%}$} & 6.0 & 3 & \multirow[t]{5}{*}{15} \\
\hline & & & 6.5 & 3 & \\
\hline & & & 7.0 & 3 & \\
\hline & & & 7.5 & 3 & \\
\hline & & & 8.0 & 3 & \\
\hline & & \multirow[t]{5}{*}{$\mathrm{AC}_{\text {Scrapped-tire }} 100 \%$} & 6.0 & 3 & \multirow[t]{5}{*}{15} \\
\hline & & & 6.5 & 3 & \\
\hline & & & 7.0 & 3 & \\
\hline & & & 7.5 & 3 & \\
\hline & & & 8.0 & 3 & \\
\hline & \multicolumn{4}{|c|}{ Total number of samples in stage 1} & 45 \\
\hline \multirow[t]{7}{*}{2.} & \multirow{6}{*}{$\begin{array}{l}\text { Marshall } \\
\text { immersion }\end{array}$} & \multirow[t]{2}{*}{$\mathrm{AC}_{\text {Standard }}$} & \multirow{2}{*}{\multicolumn{2}{|c|}{$\begin{array}{l}\text { immersion in } 30 \text { minutes } \\
\text { immersion in } 24 \text { hours }\end{array}$}} & 2 \\
\hline & & & & & 2 \\
\hline & & \multirow[t]{2}{*}{$\mathrm{AC}_{\text {Scrapped-tire } 50 \%}$} & \multirow{2}{*}{\multicolumn{2}{|c|}{$\begin{array}{l}\text { immersion in } 30 \text { minutes } \\
\text { immersion in } 24 \text { hours }\end{array}$}} & 2 \\
\hline & & & & & 2 \\
\hline & & \multirow[t]{2}{*}{$\mathrm{AC}_{\text {Scrapped-tire } 100 \%}$} & \multirow{2}{*}{\multicolumn{2}{|c|}{$\begin{array}{l}\text { immersion in } 30 \text { minutes } \\
\text { immersion in } 24 \text { hours }\end{array}$}} & 2 \\
\hline & & & & & 2 \\
\hline & \multicolumn{4}{|c|}{ Total number of samples in stage 2} & 12 \\
\hline
\end{tabular}




\section{Results and Discussion}

\subsection{Aggregate Testing Results}

Aggregate tests were conducted to determine the aggregate physical properties and characteristics of coarse aggregate, fine aggregate, scrapped tire rubber, and filler. The physical properties of the coarse aggregate, fine aggregate, filler, and chemical content of scrapped tire rubber can be seen in Table 3 and Table 4. Based on Table 3, the physical properties of coarse aggregate (crushed stone) are the bulk specific gravity of coarse aggregate is 2.59 (minimum specification 2.50), water absorption 1.47\% (maximum specification 3\%), the abrasion with Los Angeles Machine 22.75\% (maximum specification 40\%), the adhesive of aggregate and asphalt $97 \%$ (minimum specification $95 \%$ ), and the determination of flakiness index of coarse aggregate is $24.68 \%$ (maximum specification 25\%). It means that the crushed stone is comply with the required specification and can be used as coarse aggregate in asphalt concrete mixture.

Based on Table 4, the physical properties of fine aggregate, filler, and scrapped tire rubber: the bulk specific gravity of fine aggregate is 2.55 (minimum specification 2.50), water absorption of fine aggregate is $2.60 \%$ (maximum specification $3 \%$ ), specific gravity of stone ash as filler is 2.67 , and specific gravity of scrapped tire rubber is 0.972 . The bulk specific gravity of fine aggregate was found to have lower value as compared to coarse aggregate. The lowest specific gravity 0.972 was obtained for scrapped tire rubber as compared to coarse aggregates, fine aggregate and coarse aggregate. The water absorption tests on aggregate reflect the porosity and found that porosity of the aggregate decreased with the addition of binder material. It can be noted from the test results that the water absorption of fine aggregate showed $2.60 \%$ and water absorption of coarse aggregate (crushed stone) showed $1.47 \%$. This result is in line with the findings of Perumal and Anandan [27] that the addition of binder in fly ash resulted in refined pore structure and hence resulted in reduction in water absorption. The addition of binder materials such as bentonite, metakaolin, furnace slag, and cement can possibly lead to pore filling effect with fly ash particles [27].

Table 3. Physical properties of coarse aggregate: crushed stone.

\begin{tabular}{|c|c|c|c|c|c|}
\hline \multirow{2}{*}{ Tests } & \multirow{2}{*}{ Unit } & \multirow{2}{*}{ Value } & \multicolumn{2}{|c|}{ Specification } & \multirow{2}{*}{ Standard } \\
\hline & & & Min. & Max. & \\
\hline Bulk specific gravity & - & 2.59 & 2.50 & - & SNI 1969: 2008 \\
\hline Water absorption & $\%$ & 1.47 & - & 3.0 & SNI 1969: 2008 \\
\hline Abrasion with Los Angeles machine & $\%$ & 22.75 & - & 40.0 & SNI 2417: 2008 \\
\hline Adhesive of aggregate and asphalt & $\%$ & 97 & 95 & - & SNI 03-2439-1991 \\
\hline Flakiness index of coarse aggregate & $\%$ & 24.68 & - & 25.0 & SNI-M-25-1991-03 \\
\hline
\end{tabular}

Table 4. Physical properties of fine aggregate, filler, and scrapped tire rubber.

\begin{tabular}{llllll}
\hline \multirow{2}{*}{ Tests } & \multirow{2}{*}{ Unit } & \multirow{2}{*}{ Value } & \multicolumn{2}{l}{ Specification } & \multirow{2}{*}{ Standard } \\
\cline { 5 - 5 } & & & Min. & Max. & \\
\hline Bulk specific gravity of fine aggregate & - & 2.55 & 2.50 & - & SNI 1969: 2008 \\
Water absorption of fine aggregate & $\%$ & 2.60 & - & 3.0 & SNI 1969: 2008 \\
Specific gravity of stone ash as filler & - & 2.67 & - & - & SNI 1969: 2008 \\
Specific gravity of scrapped tire rubber & - & 0.972 & - & - & SNI 1969: 2008 \\
\hline
\end{tabular}

\subsection{Asphalt Test Results}

Asphalt test was conducted to determine the characteristics of material were used in asphalt concrete mixture. Asphalt from PERTAMINA with penetration 60-70 was used in this study. Asphalt test includes penetration, softening point of asphalt, flash and fire point, ductility, specific gravity, and viscosity of asphalt. The asphalt test results can be seen in Table 5. The result of penetration test in temperature $25^{\circ} \mathrm{C}$ with load 100 gram is $69.0 \mathrm{dmm}$ (minimum specification $60 \mathrm{dmm}$ and maximum specification $79 \mathrm{dmm}$ [23]). The softening point of asphalt based on ring and ball test method is $51.1^{\circ} \mathrm{C}$. Based on the penetration value and the softening 
point of asphalt can be analyzed the penetration index. The penetration index of asphalt is -0.128 , the negative value mean that asphalt is sensitive with the temperature.

Flash and fire points of asphalt using Cleveland open cup [24] and get the value of the flash point of asphalt is $262.6^{\circ} \mathrm{C}$ (minimum specification $200^{\circ} \mathrm{C}$ ) and the fire point of asphalt is $285.7^{\circ} \mathrm{C}$. The ductility of asphalt in temperature $25^{\circ} \mathrm{C}$ is $120.5 \mathrm{~cm}$ (minimum specification $100 \mathrm{~cm}$ ). The specific gravity of asphalt is 1.047 (minimum specification 1.0). Asphalt from PERTAMINA is comply with the required specification and can be used as bitumen in asphalt concrete mixture. Maximum specific gravity is required to determine the mixture's asphalt absorption, percent of air voids in the compacted bituminous paving mixture, percent of voids in mineral aggregate [28].

Table 5. Asphalt test results.

\begin{tabular}{llllll}
\hline \multirow{2}{*}{ Tests } & \multirow{2}{*}{ Unit } & \multicolumn{2}{l}{ Specification } & \multirow{2}{*}{ Result } & \multirow{2}{*}{ Standard } \\
\cline { 3 - 5 } & & Min. & Max. & & \\
\hline Penetration,25 $5^{\circ} \mathrm{C}, 100$ gram, $5 \mathrm{sec}$. & $\mathrm{dmm}$ & 60 & 79 & 69.0 & SNI 06-2456-1991 \\
Softening point of asphalt & ${ }^{\circ} \mathrm{C}$ & 48 & 58 & 51.1 & SNI 06-2434-1991 \\
Flash point of asphalt & ${ }^{\circ} \mathrm{C}$ & 200 & - & 262.6 & SNI 06-2433-1991 \\
Fire point of asphalt & ${ }^{\circ} \mathrm{C}$ & - & - & 285.7 & SNI 06-2433-1991 \\
Ductility, $25^{\circ} \mathrm{C}$ & $\mathrm{cm}$ & 100 & - & 120.5 & SNI 06-2432-1991 \\
Specific gravity of asphalt & - & 1 & - & 1.047 & SNI 06-2441-1991 \\
Viscosity test in $120^{\circ} \mathrm{C}$ & $\mathrm{cSt}$ & Time: 435 seconds & 948.30 & \\
Viscosity test in $140^{\circ} \mathrm{C}$ & $\mathrm{cSt}$ & Time: 151 seconds & 329.18 & ASTM E 102-93 \\
Viscosity test in $160^{\circ} \mathrm{C}$ & $\mathrm{cSt}$ & Time: 54 seconds & 117.72 & \\
\hline
\end{tabular}

Viscosity test is done using Saybolt-Furol with standard test method ASTM E-102-93 [29]. Furol is abbreviation from fuel and road oils. The data from the viscosity test results, then plotted on the semilogarithmic graph (relationship between the kinematic viscosities $(\mathrm{cSt}$ ) with the temperature in degrees Celsius $\left({ }^{\circ} \mathrm{C}\right)$, is shown in Fig. 6. A kinematic viscosity is viscosities from bitumen with cut back bitumen type. Kinematic viscosity was determined using Eq. (1).

in which:

$$
\text { Kinematic viscosity }(\mathrm{cSt})=\text { SFS } \times \text { FK }
$$

SFS = viscosity of Saybolt-Furol in seconds.

FK $=$ correction factor, $\mathrm{FK}=2.18$.

From Fig. 6, the mixture temperature in 170 centistokes is $153.75^{\circ} \mathrm{C}$ and the compaction temperature in 280 centistokes is $144.15^{\circ} \mathrm{C}$. The relationship between kinematic viscosities (in centistokes) with temperature is formulated in exponential function with Eq. (2). Coefficient determination $\left(\mathrm{r}^{2}\right)$ value is 0.99 .

in which:

$$
\mathrm{Y}=493,262 \mathrm{e}^{-0.052 \mathrm{x}} \text { with } \mathrm{r}^{2}=0.99
$$

$\mathrm{Y}=$ kinematic viscosities of asphalt (in $\mathrm{cSt}$ ) and

$\mathrm{X} \quad=$ temperature in degrees Celsius $\left({ }^{\circ} \mathrm{C}\right)$. 


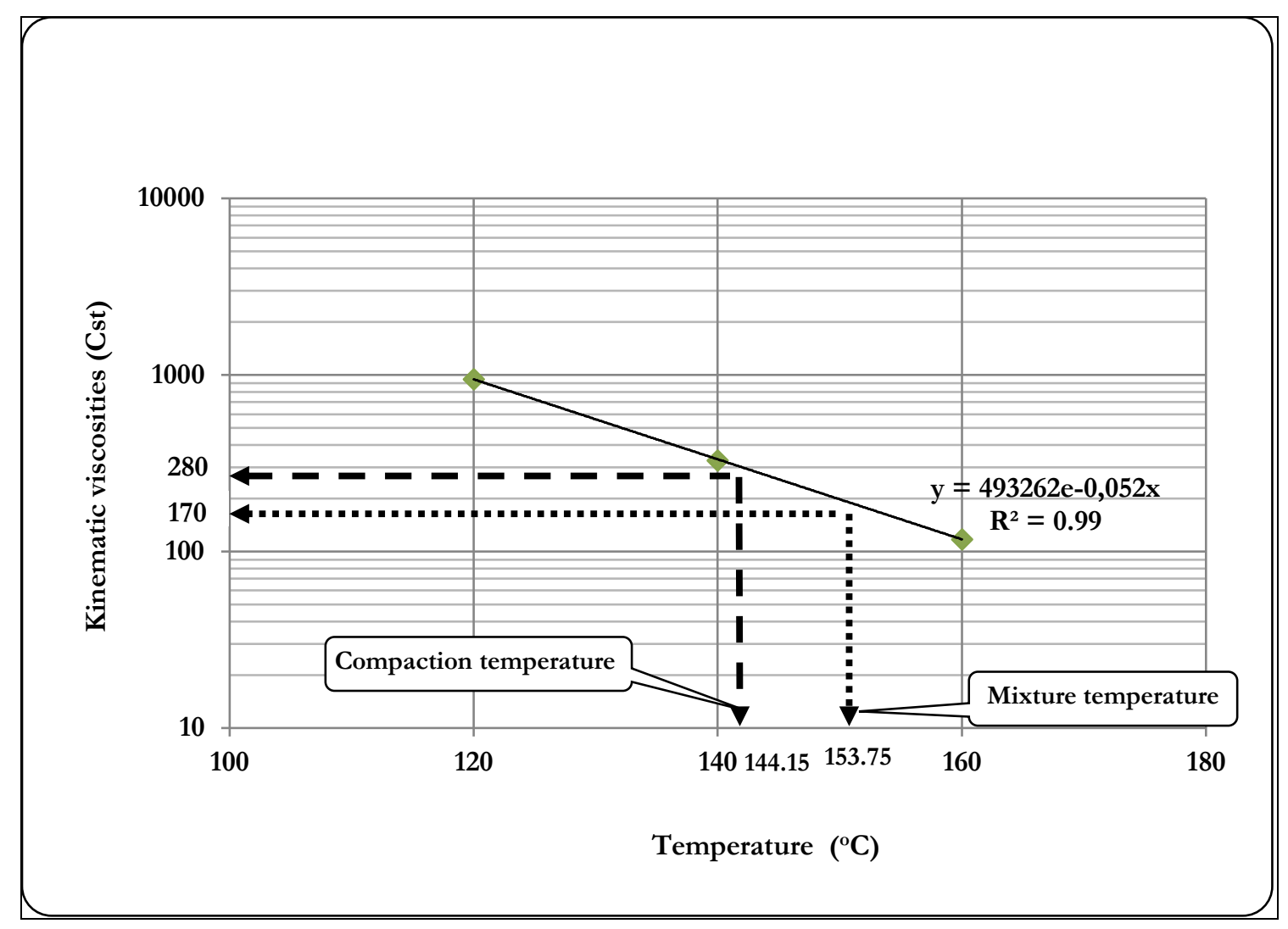

Fig. 6. Relationship between the kinematic viscosities $(\mathrm{cSt})$ with temperature $\left({ }^{\circ} \mathrm{C}\right)$.

\subsection{Marshall Test Result}

Marshall test based on ASTM D6927-06 [30]. Marshall test results for the AC Standard $_{\text {mixture with asphalt }}$ content range from $6 \%$ to $8 \%$. There are six characteristics of Marshall Test: Void in Mineral Aggregate (VMA, \% volume), Void in Mixture (VIM, \% volume), Voids Filled with Bitumen (VFB, \% VMA), stability $(\mathrm{kg})$, flow $(\mathrm{mm})$, and Marshall Quotient (MQ). Specification for Marshall test based on Pedoman Konstruksi Bangunan No. 001-03/BM/2006 [31].

Marshall Test results for $\mathrm{AC}_{\text {Standard }}$ mixture, $\mathrm{AC}_{\text {Scrapped-tire } 50 \%}$ mixture, and $\mathrm{AC}_{\text {Scrapped-tire } 100 \%}$ mixture can be seen in Fig. 7 through Fig. 12. The relationship between stability $(\mathrm{kg})$ with asphalt content can be seen in Fig. 7. Relationship between flow with asphalt content can be seen in Fig. 8. The relationship between Marshal Quotients with asphalt content can be seen in Fig. 9. The relationship between void in mixture with asphalt content can be seen in Fig. 10. Relationship between void in mineral aggregate with asphalt content can be seen in Fig. 11. In Fig. 12, can be seen the relationship between voids filled with bitumen with asphalt content.

Based on the Pedoman Konstruksi Bangunan No. 001-03/BM/2006 [31] the minimum requirement value for stability of AC mixture is $1,000 \mathrm{~kg}[17,31]$, so that three types of asphalt concrete mixtures preoccupied the specified requirements. Asphalt content from $6.0 \%$ to $7.9 \%$ is complying with the required specification. The flow test of $\mathrm{AC}_{\text {Standard }}$ mixture and $\mathrm{AC}_{\text {Scrapped-tire } 100 \%}$ mixture are complying with the required specification for the asphalt content from $6.0 \%$ to $8.0 \%$ but $\mathrm{AC}_{\text {Scrapped-tire }} 50 \%$ mixture from $6.8 \%$ to $8.0 \%$. Scrapped tire rubber is not porous, crushed stone aggregate absorbs the asphalt but scrapped tire rubber doesn't [32]. Minimum specification of flow value for AC mixture is $3 \mathrm{~mm}$ [17, 31]. The Marshall Quotient values for $\mathrm{AC}_{\text {Standard }}$ mixture is $287.48 \mathrm{~kg} / \mathrm{mm}-449.45 \mathrm{~kg} / \mathrm{mm}, \mathrm{AC}_{\text {Scrapped-tire } 50 \%}$ mixture is $211.30 \mathrm{~kg} / \mathrm{mm}-473.38 \mathrm{~kg} / \mathrm{mm}$, and for the $\mathrm{AC}_{\text {Scrapped-tire } 100 \%}$ mixture is $203.16 \mathrm{~kg} / \mathrm{mm}-462.21 \mathrm{~kg} / \mathrm{mm}$. $\mathrm{AC}_{\text {Standard }}$ mixture is more rigid than

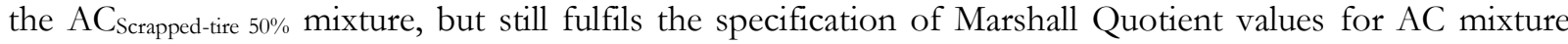
(minimum $250 \mathrm{~kg} / \mathrm{mm}$ ) [26]. The Marshall Quotient values for $\mathrm{AC}_{\text {Standard }}$ mixture is complying with the required specification for the asphalt content from $6.0 \%-8.0 \%$ and $6.0 \%-7.7 \%$ for $\mathrm{AC}_{\text {Scrapped-tire } 50 \% \text { mixture }}$ and $\mathrm{AC}_{\text {Scrapped-tire } 100 \%}$ mixture. 


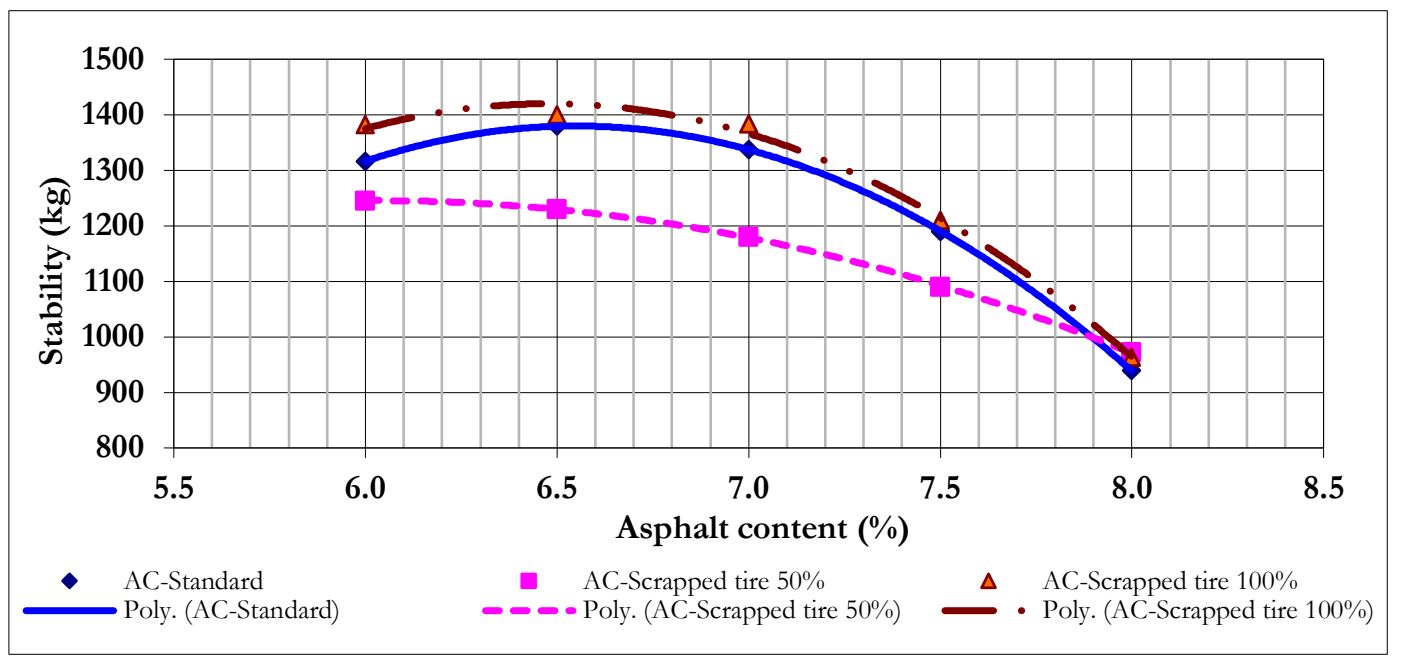

Fig. 7. Relationship between stability (kg) with asphalt content (\%).

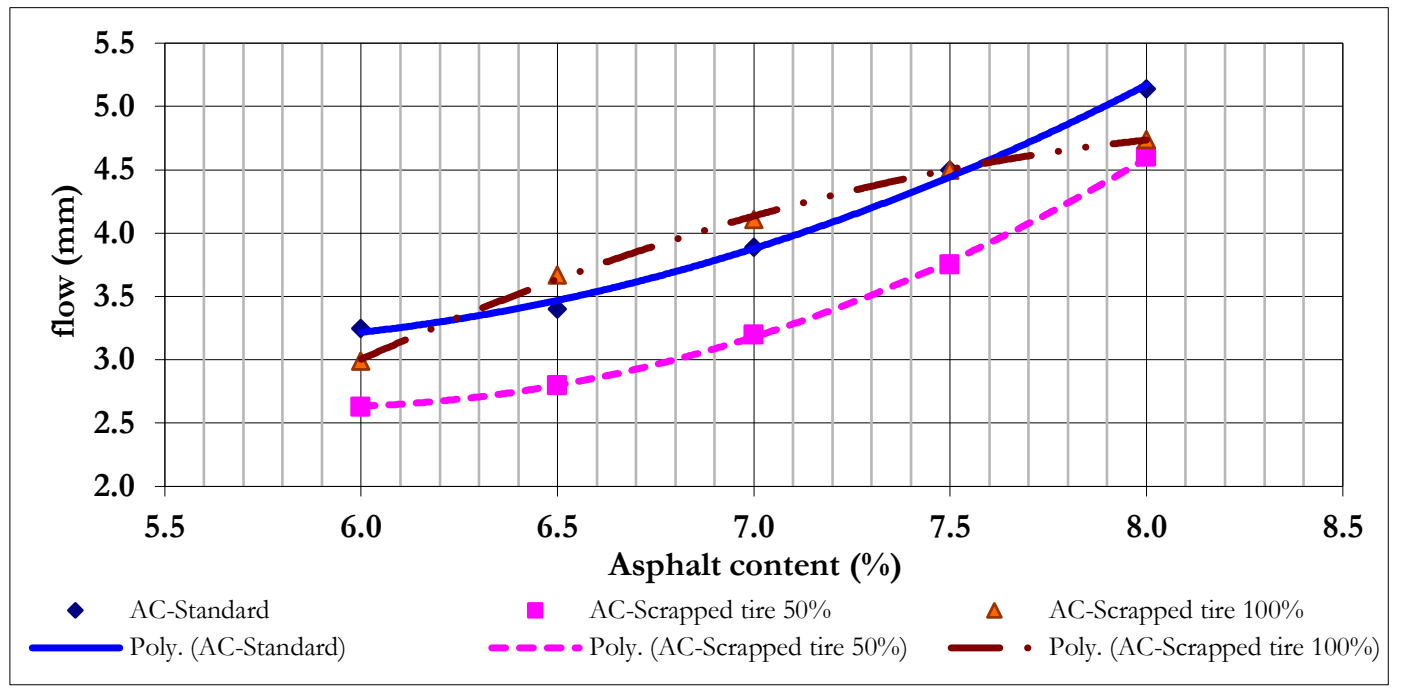

Fig. 8. Relationship between flow ( $\mathrm{mm})$ with asphalt content (\%).

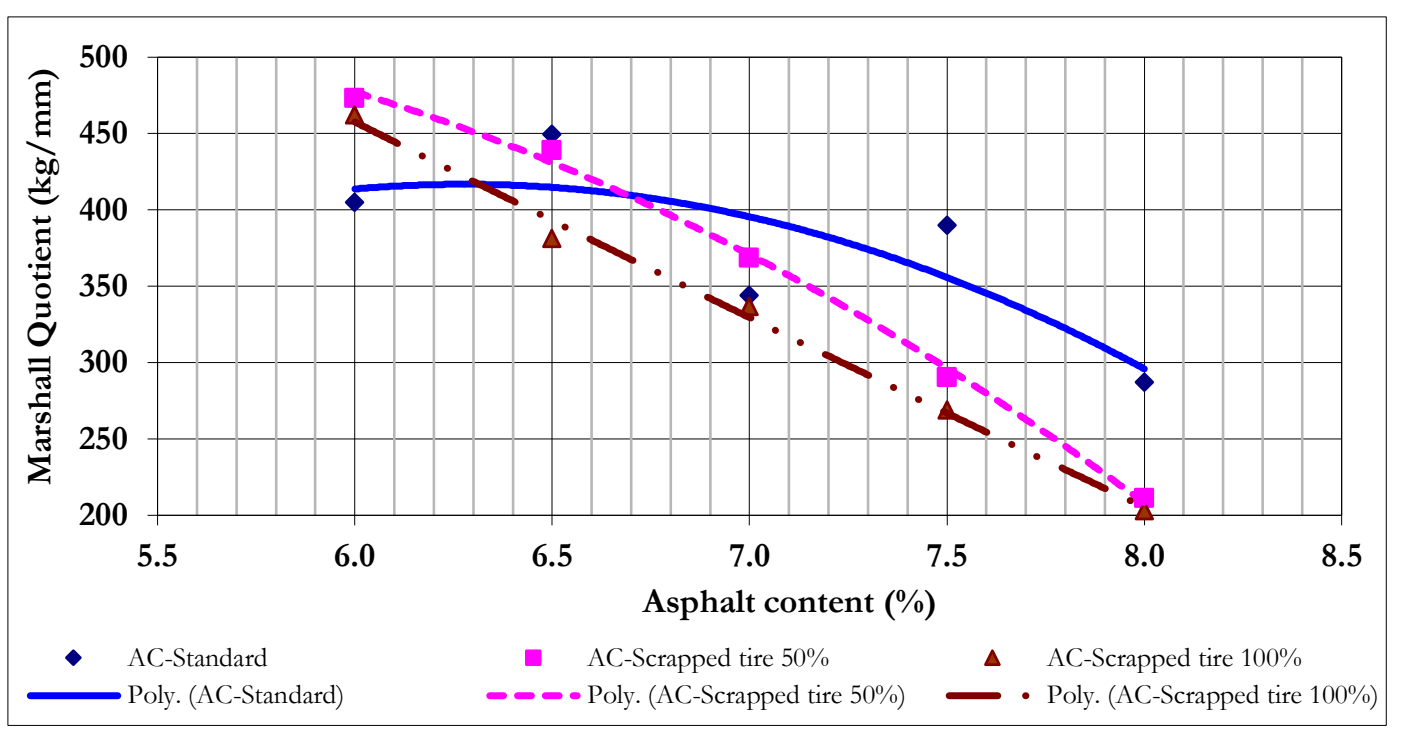

Fig. 9. Relationship between Marshall Quotient $(\mathrm{kg} / \mathrm{mm})$ with asphalt content $(\%)$. 


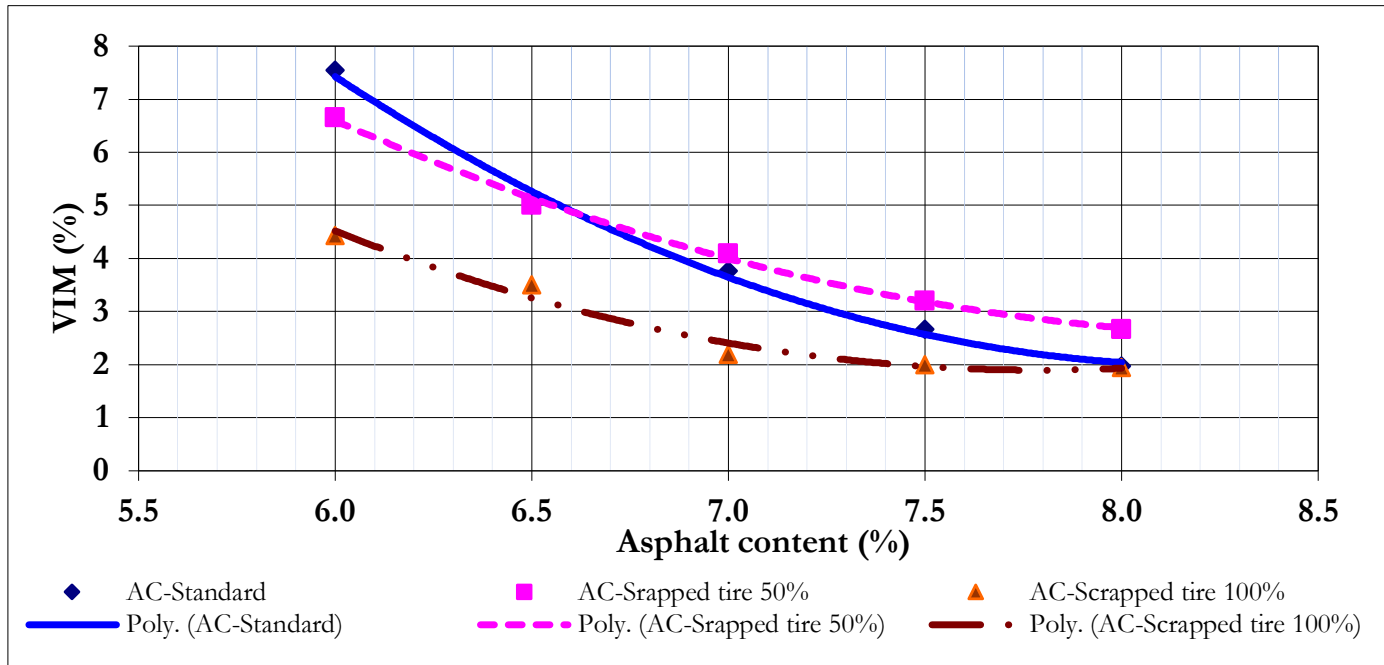

Fig. 10. Relationship between the void in mixture (\%) with asphalt content $(\%)$.

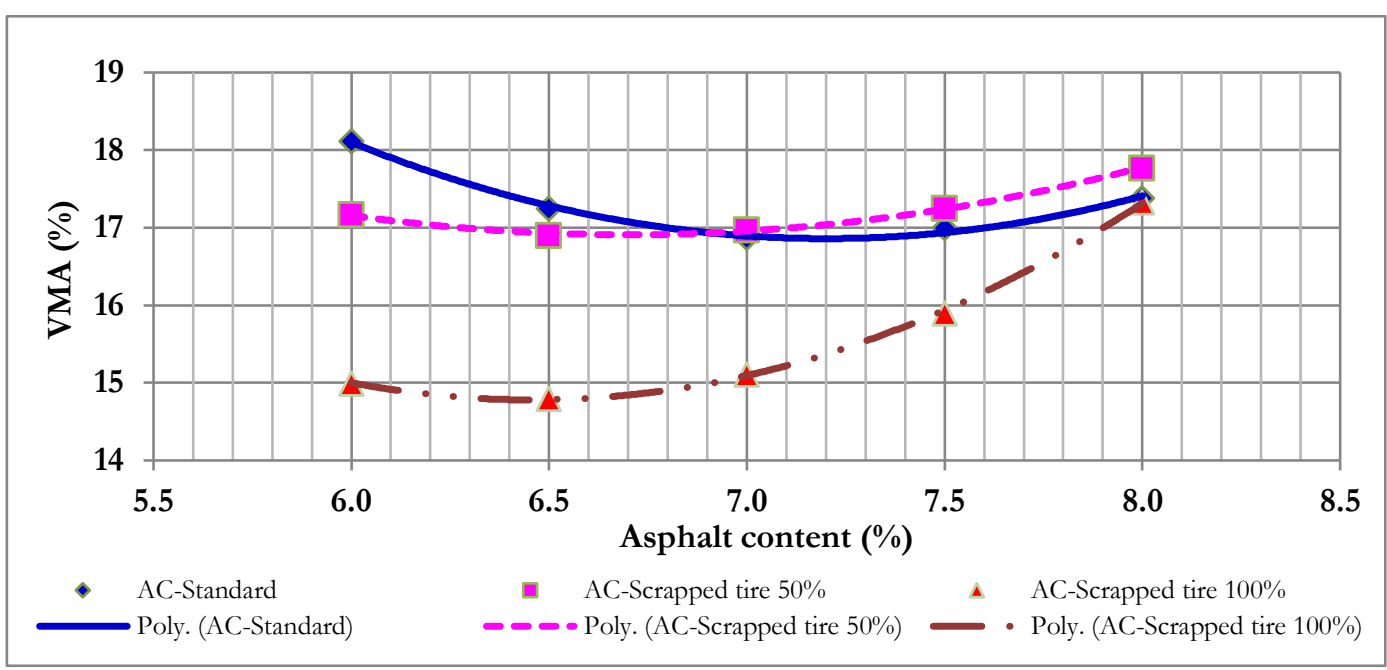

Fig. 11. Relationship between void in mineral aggregate (\%) with asphalt content $(\%)$.

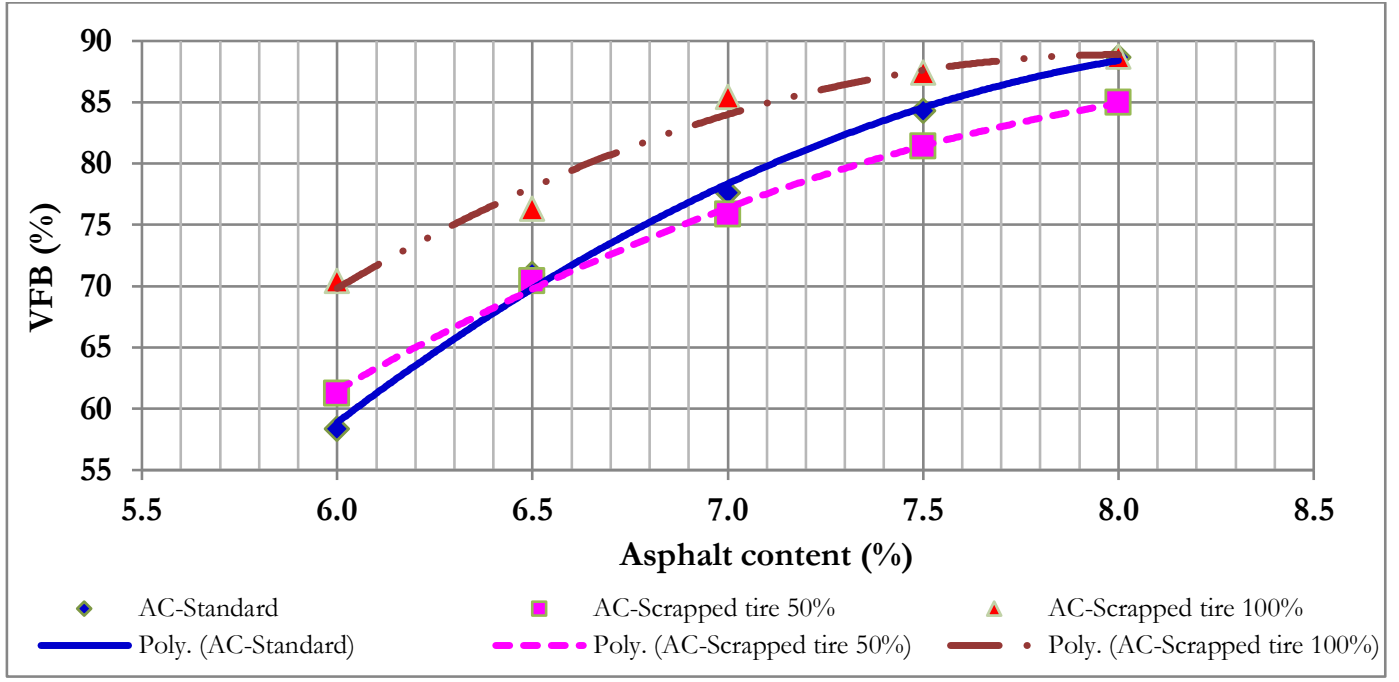

Fig. 12. Relationship between the voids filled with bitumen (\%) with asphalt content (\%). 
The determination of optimum asphalt content value for the $\mathrm{AC}_{\text {Standard }}$ mixture, $\mathrm{A} \mathrm{C}_{\text {Scrapped-tire }} 50 \%$ mixture, and $\mathrm{AC}_{\text {Scrapped-tire }}$ 100\% mixture is shown in Fig. 13, Fig. 14, and Fig. 15, respectively. For the AC $\mathrm{Standard}_{\text {mixture, }}$ from the six characteristics of Marshall Test: VMA, flow, and Marshall Quotient value are appropriate for asphalt content from 6\%-8\%. Stability value is appropriate for asphalt content from 6\%-7.9\%, VIM appropriate for asphalt content from $6.4 \%-7.15 \%$ and VFB for asphalt content $6.2 \%-8 \%$. The asphalt content that can satisfy all specification of Marshall Test is from $6.40 \%$ to $7.15 \%$. The value of optimum asphalt content of the $\mathrm{AC}_{\text {Standard }}$ mixture is the median $6.40 \%$ to $7.15 \%$ is $6.78 \%$ (indicated by the blue arrow in Fig. 13). For the $\mathrm{AC}_{\text {Scrapped-tire } 50 \%}$ mixture, asphalt content that satisfies to six characteristics of Marshall Test is $6.80 \%$ to $7.40 \%$. The value of optimum asphalt content of the $\mathrm{AC}_{\text {Scrapped-tire }} 50 \%$ mixture is $7.10 \%$ (indicated by the blue arrow in Fig. 14).

For the $\mathrm{AC}_{\text {Scrapped-tire }} 100 \%$ mixture, from the six characteristics of Marshall Test: Flow, VMA, and VFB value are appropriate for asphalt content from 6\%-8\%. Stability value is appropriate for asphalt content from 6\%-7.9\%, VIM appropriate for asphalt content from 6.0\%-6.45\% and Marshall Quotient for asphalt content 6\%-7.65\%. The asphalt content that satisfies to the six characteristics of Marshall Test is $6.00 \%$ to $6.45 \%$. The value of optimum asphalt content of the $\mathrm{AC}_{\text {Scrapped-tire }} 100 \%$ mixture is $6.22 \%$ (indicated by the blue arrow in Fig. 15).

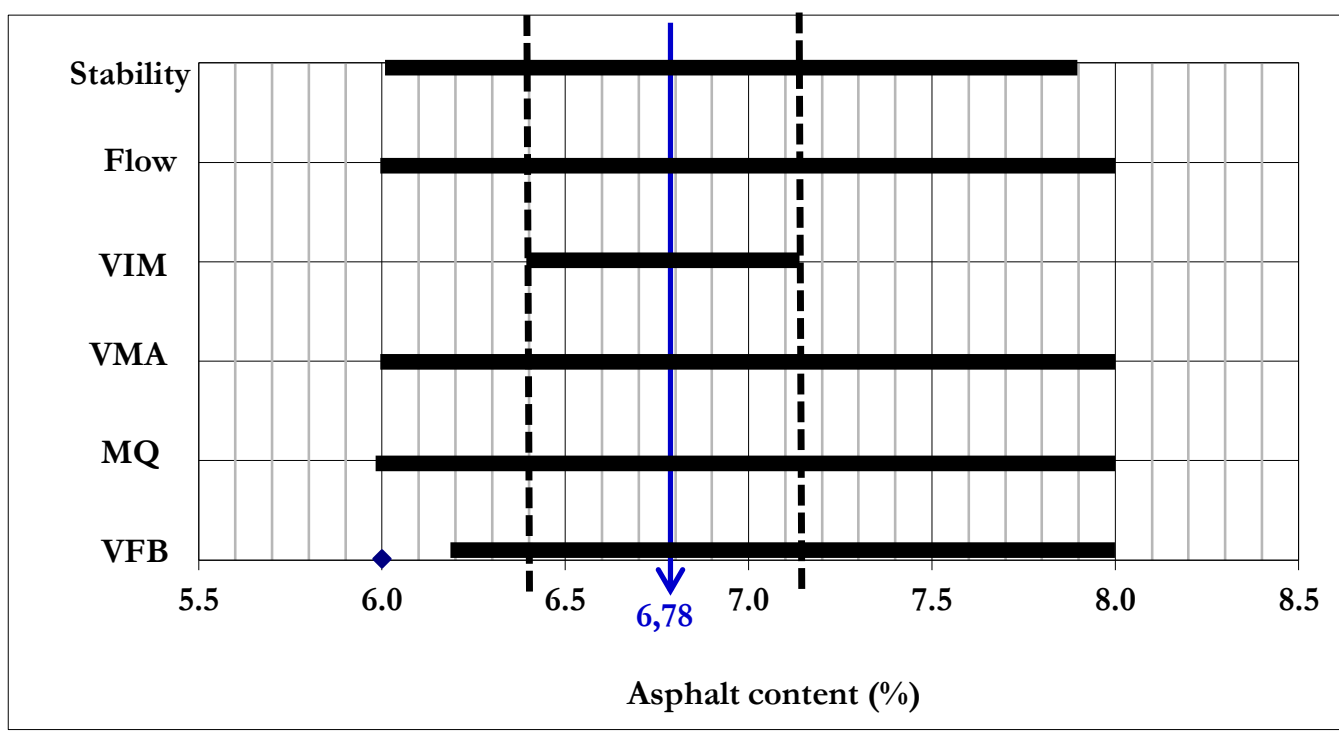

Fig. 13. Determination of optimum asphalt content from $A C_{\text {Standard }}$ mixture.

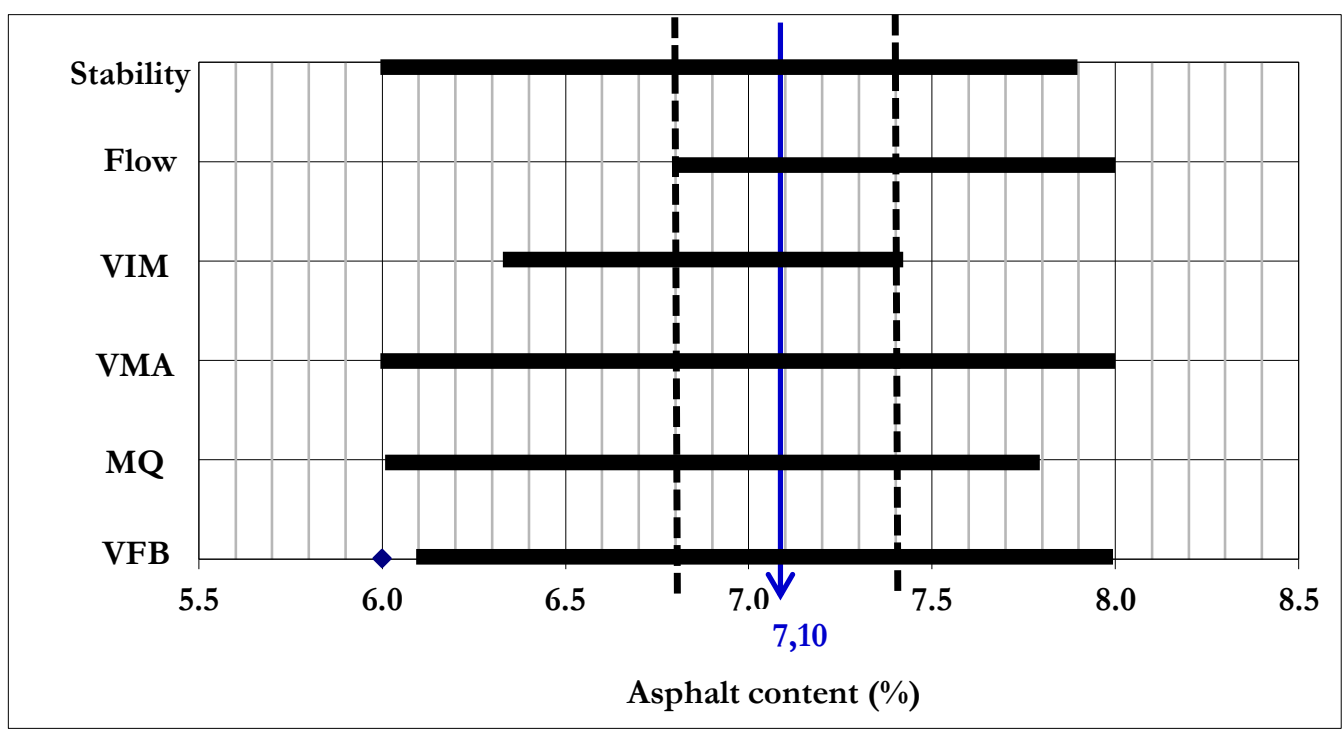

Fig. 14. Determination of optimum asphalt content from $\mathrm{AC}_{\text {Scrapped-tire } 50 \%}$ mixture. 


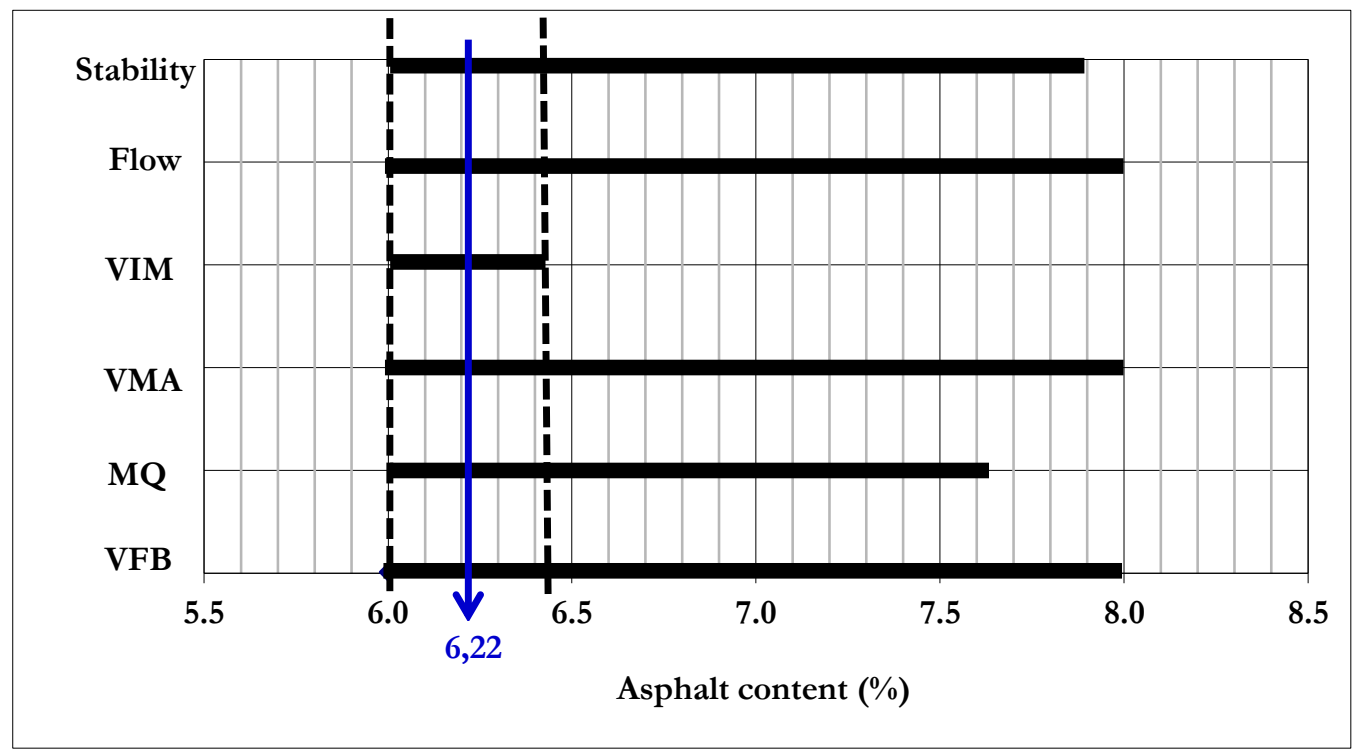

Fig. 15. Determination of optimum asphalt content from $\mathrm{AC}_{\text {scrapped-tire }} 100 \%$ mixture.

Based on the Marshall Test, the optimum asphalt contents for $\mathrm{AC}_{\text {Standard }}$ mixture is 6.78\%, $\mathrm{AC}_{\text {Scrapped-tire }}$ $50 \%$ mixture is $7.10 \%$, and $\mathrm{AC}_{\text {Scrapped-tire }} 100 \%$ mixture is $6.22 \%$. This result is similar to the research of Kurniati [33] and Novianto [34]. The optimum asphalt content with scrapped rubber tires in Asphalt Concrete (AC) mixtures is larger than the natural stone. The value of optimum asphalt content for the mixture using scrapped rubber tires is $7.40 \%$, whereas optimum asphalt content values for the mixture using natural stone is $7.10 \%$ [33].

Table 6. Marshall test characteristic for asphalt concrete in optimum asphalt content.

\begin{tabular}{|c|c|c|c|c|}
\hline \multicolumn{4}{|c|}{ Characteristic of Mixture type } & \multirow{2}{*}{$\begin{array}{l}\text { Specification AC } \\
\text { Mixture }\end{array}$} \\
\hline mixture & $\overline{\mathbf{A C}_{\text {Standard }}}$ & $\mathbf{A C}_{\text {Scrapped-tire } 50 \%}$ & $\mathbf{A C}_{\text {Scrapped-tire } 100 \%}$ & \\
\hline Asphalt content $(\%)$ & 6.78 & 7.10 & 6.22 & - \\
\hline VMA (\%) & 17.05 & 17.15 & 17.00 & Min \\
\hline VIM (\%) & 4.20 & 3.85 & 3.90 & $3.50-5.50 \%$ \\
\hline VFB (\%) & 75 & 77.50 & 73.50 & Min. 63\% \\
\hline Stability $(\mathrm{kg})$ & $1,366.87$ & $1,164.06$ & $1,406.93$ & Min. $1,000 \mathrm{~kg}$ \\
\hline Flow $(\mathrm{mm})$ & 3.75 & 3.25 & 3.30 & Min. $3.00 \mathrm{~mm}$ \\
\hline $\mathrm{MQ}(\mathrm{kg} / \mathrm{mm})$ & 405.60 & 356.96 & 429.09 & Min. $250 \mathrm{~kg} / \mathrm{mm}$ \\
\hline
\end{tabular}

Voids in Mixture (VIM) value of optimum asphalt content AC $_{\text {Standard }}$ mixture is $4.20 \%$ while for the AC Scrapped-tire $50 \%$ mixture is $3.85 \%$ and for the $\mathrm{AC}_{\text {scrapped-tire }} 100 \%$ mixture is $3.90 \%$. The differences of VIM value are due to differences in levels of asphalt content and density values. It is very important to maintain the value of VIM [35]. The VIM value required for AC mixture is between 3.50\%-5.50\% [17, 31]. The mixture in that range or interval is not susceptible to melting, flowing, and plastic deformation [34]. The stability value of optimum asphalt content to $\mathrm{AC}_{\text {Standard }}$ is $1,366.87 \mathrm{~kg}$ while for the $\mathrm{AC}_{\text {Scrapped-tire } 50 \%}$ mixture is $1,164.06$ $\mathrm{kg}$ and for the $\mathrm{AC}_{\text {Scrapped-tire }} 100 \%$ mixture is $1,406.93 \mathrm{~kg}$. Crushed stone aggregate has abrasion and level of hardness better than one of scrapped rubber tire $[32,35]$. In addition, the scrapped tire rubber is round, easily broken, and unfavorable aggregate interlocking making stability of $\mathrm{AC}_{\text {Scrapped-tire } 50 \% \text { mixture lower than }}$

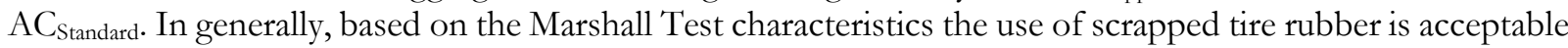
as a partial replacement of aggregate in asphalt concrete mixtures for road surface layers.

\subsection{Marshall Immersion Test Result}

After the optimum bitumen content of each mixture is obtained, then testing the Marshall Immersion that divided into two groups: the first group was immersed for 30 minutes at $60^{\circ} \mathrm{C}$ and the second group was 
immersed for 24 hours at the temperature of $60^{\circ} \mathrm{C}$ then testing Marshall. By comparing the immersion stability for 24 hours $\left(\mathrm{S}_{2}\right)$ with the stability of immersion for 30 minutes $\left(\mathrm{S}_{1}\right)$, was obtained the Retained Strength Index (RSI) of each mixture. The results from the Marshall Immersion test can be seen in Table 7, while the relationship between each of mixed type with an index of immersion can be seen in Fig. 16.

Table 7. Marshall Immersion test result.

\begin{tabular}{|c|c|c|c|c|}
\hline $\begin{array}{l}\text { Mixture } \\
\text { type }\end{array}$ & $\begin{array}{c}\text { Optimum } \\
\text { asphalt content } \\
(\%)\end{array}$ & $\begin{array}{c}\text { Standard stability } \\
\left(30 \text { minutes, } 60^{\circ} \mathrm{C}\right) \\
(\mathrm{kg})\end{array}$ & $\begin{array}{c}\text { Stability immersion } \\
\left(24 \text { hours, } 60^{\circ} \mathrm{C}\right) \\
(\mathrm{kg})\end{array}$ & $\begin{array}{l}\text { Retained strength } \\
\text { index } \\
(>75 \%)\end{array}$ \\
\hline $\mathrm{AC}_{\text {Standard }}$ mixture & 6.78 & $1,437.5$ & 1,280 & 89.04 \\
\hline $\mathrm{AC}_{\text {Scrapped-tire } 50 \%}$ mixture & 7.10 & 964.25 & 931 & 96.55 \\
\hline AC $_{\text {Scrapped-tire } 100 \%}$ mixture & 6.22 & 885.5 & 822 & 92.83 \\
\hline
\end{tabular}

Resilience the $\mathrm{AC}_{\text {Standard }}$ mixture by $89.04 \%$ smaller than the $\mathrm{AC}_{\text {Scrapped-tire }} 50 \%$ mixture is $96.55 \%$ and $\mathrm{AC}_{\text {Scrapped-tire } 100 \%}$ mixture is 92.83 , but all of the value is still greater than that required by Indonesia Highways $75 \%$ [17]. Immersion index for $\mathrm{AC}_{\text {Standard }}$ mixture is smallest (89.04\%) when compared to the $\mathrm{AC}_{\text {Scrapped-tire }} 50 \%$ mixture and $\mathrm{AC}_{\text {scrapped-tire }} 100 \%$ mixture. Mixture with $50 \%$ aggregate substitute in fraction No. 50 has the highest resistance to water $(93.09 \%$ ) when compared to the mixture with $100 \%$ replacement of aggregate at fraction No. $50(91.81 \%)$ and the mixture without any scrap tires $(91.07 \%)$. Asphalt concrete mixture with $50 \%$ and $100 \%$ replacement of aggregate at fraction No. 50 has a smaller tensile resistance when compared with a mixture without tires (ACstandard). The use of scrapped tire rubber in asphalt concrete mixtures can improve the resistance to permanent deformation due to ruts [33]. The addition of scrapped tire rubber up to $\pm 3 \%$ in the asphalt concrete mixture; produce a better performance than the asphalt concrete standard mixture to the conditions of temperature above $30^{\circ} \mathrm{C}$ [34]. The addition of powder materials such as scrapped tires rubber in asphalt mixture can provide better resistance to high temperatures and loads, as compared with asphalt without the addition material. The addition of additive in asphalt concrete mixture can improve the shear resistance at high temperature to prevent the damage of road [36].

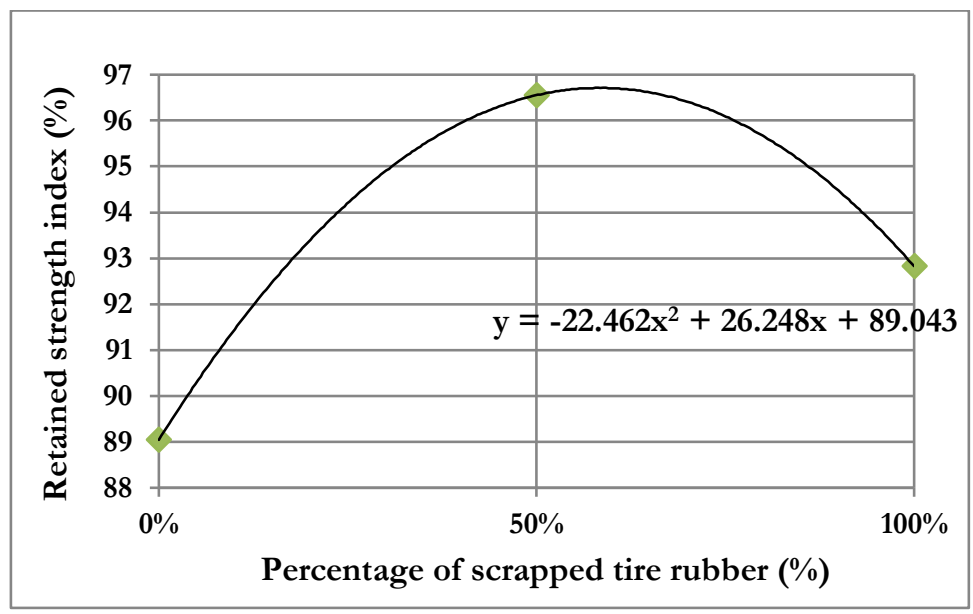

Fig. 16. Relationship between retained strength index (\%) with percentage of scrapped tire rubber (\%).

\section{Conclusions}

Based on the results, the following conclusion can be drawn:

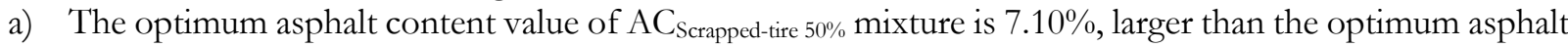
content of $\mathrm{AC}_{\text {Standard }}$ mixture at $6.78 \%$ and $\mathrm{AC}_{\text {Scrapped-tire } 100 \%}$ mixture at $6.22 \%$.

b) Based on the Marshall Test characteristics, scrapped tire rubber can be used as an alternative material to replace fine aggregate in AC mixtures for road surface layer to produce larger voids filled with bitumen than $\mathrm{AC}_{\text {Standard. }}$. 
c) The use of scrapped tire rubber in asphalt concrete mixtures can improve the resistance to permanent deformation due to ruts and provide better resistance to high temperatures and loads.

d) Recommendation for the next research is to investigate the optimum percentage of scrapped tire rubber to get the higher stability and voids in mixture value than the $\mathrm{AC}_{\text {Standard. }}$.

\section{References}

[1] C. Cheng, S. Pouffary, N. Svenningsen, and M. Callaway, "The Kyoto Protocol, the clean development mechanism and the building and construction sector," A report for The UNEP Sustainable Buildings and Construction Initiative, United Nations Environment Programme (UNEP), Paris, France, 2008. Available: http://www.unep.org/sbci/pdfs/BuildingsandCDMreporte-version.pdf [Accessed: Dec. 25, 2014].

[2] N. Ganesan, J. B. Raj, and A. P. Shashikala, "Flexural fatigue behavior of self-compacting rubberized concrete," Construction and Building Materials, vol. 44, pp. 7-14, 2013.

[3] A. A. Aziz, S. P. Rao, and E. Salleh, "Waste tyres as heat sink to reduce the driveway surface temperatures in Malaysia," Journal of Design and Built Environment, vol. 13, pp. 1-11, 2013.

[4] ETRMA, "End of Life Tires A valuable resource with a wealth of potential," Report 2006, European Tyre and Rubber Manufactures Association (ETRMA), Brussel, 2006.

[5] Rubber Manufacturer's Association. (2000). NW Suite 900, Washington D.C.

[6] B. Lebreton and A. Tuma, "A quantitative approach to assessing the profitability of car and truck tire remanufacturing," International Journal of Production Economics, vol. 100, pp. 639-652, 2006.

[7] A. M. Maleka, I. A. Alkali, and R. P. Jaya, "The indirect tensile strength of palm oil fuel ash (POFA) modified asphaltic concrete," Applied Mechanics and Materials, vol. 587-589, pp. 1270-1275, 2014.

[8] M. W. Tantala, J. A. Lepore and I. Zandi, "Quasi-elastic behavior of rubber included concrete," in Proceedings $12^{\text {th }}$ International Conf. on Solid Waste Technology and Management, Philadelphia, 1996.

[9] K. Aoudia, S. Azem, N.A. Hocine, M. Gratton, V. Pettarin, and S. Seghar, "Recycling of waste tire rubber: Microwave devulcanization and incorporation in a thermoset resin," Waste Management, vol. 60, pp. 471-481, 2017.

[10] D. L. Presti, "Recycled tyre rubber modified bitumens for road asphalt mixtures: A literature review," Construction and Building Materials, vol. 49, pp. 863-881, 2013. Availble: http://dx.doi.org/10.1016/ j.conbuildmat.2013.09.007

[11] V. F. Vazquez, J. Luong, M. Bueno, F. Teran, and S. E. Paje, "Assessment of an action against environmental noise, acoustic durability of a pavement surface with crumb rubber," Science Total Environment, vol. 542, pp. 223-230, 2016.

[12] G. H. Shafabakhsh, M. Sadeghnejad, and Y. Sajed, "Case study of rutting performance of HMA modified with waste rubber powder," Case Study Construction Material, vol. 1, pp. 69-76, 2014.

[13] S. Kocevski, S. Yagneswaran, F. Xiao, V. S. Punith, D. W. Smith Jr., and S. Amirkhanian, "Surface modified ground rubber tire by grafting acrylic acid for paving applications," Construction and Building Material, vol. 34, pp. 83-90, 2012.

[14] C. N. C. Wan, R. P. Jaya, and M. O. Hamzah, "Properties of porous asphalt mixture made with styrene butadiene styrene under long term oven ageing," Advanced Materials Research, vol. 486, pp. 378-383, 2012.

[15] A. Farina, M. C. Zanetti, E. Santagata, and G. A. Blengini, "Life cycle assessment applied to bituminous mixtures containing recycled materials: Crumb rubber and reclaimed asphalt pavement," Resources, Conservation and Recycling, vol. 117, no. 1, pp. 204-212, 2017. Available: http://dx.doi.org/10.1016/j.resconrec. 2016.10.015

[16] T. W. Kennedy, "Characterization of asphalt pavement material using the indirect tensile strength," Proceeding Association of Asphalt Paving Technology, vol. 46, San Antonio, Texas, U.S.A., 2000, pp. 132-150.

[17] Ministry of Public Works Republic of Indonesia, Campuran Beraspal Panas, Buku V Spesifikasi, Seksi 6.3 Spesifikasi Umum Jalan dan Jembatan. Jakarta: Ministry of Public Works, 2006.

[18] Directorate General of Highways (Dirjen Bina Marga), Petunjuk Pelaksanaan Lapis Aspal Beton (Laston) untuk. Jalan Raya/SKBI 2.4-26.1987 UDC: 625.75(02). Jakarta: Yayasan Badan Penerbit Pekerjaan Umum, Ministry of Public Works Indonesia, 1987.

[19] Cara Uji Berat Jenis dan Penyerapan Air Agregat Kasar, Badan Standardisasi Nasional (BSN) Indonesia, Jakarta, Standar Nasional Indonesia (SNI) 1969:2008, 2008.

[20] Cara Uji Keausan Agregat dengan Mesin Abrasi Los Angeles, Badan Standardisasi Nasional (BSN) Indonesia, Jakarta, Standar Nasional Indonesia (SNI) 2417:2008, 2008. 
[21] Metode Pengujian Kelekatan Agregat terbadap Aspal, Badan Standardisasi Nasional (BSN) Indonesia, Jakarta, Standar Nasional Indonesia (SNI) 03-2439-1991, 1991.

[22] Metode Pengujian Berat Jenis Aspal Padat, Badan Standardisasi Nasional (BSN) Indonesia, Jakarta, Standar Nasional Indonesia, (SNI)-06-2441-1991, 1991.

[23] Metode pengujian penetrasi aspal, Badan Standardisasi Nasional (BSN) Indonesia, Jakarta, Standar Nasional Indonesia, (SNI) 06-2456-1991, 1991.

[24] Metode Pengujian Titik Nyala dan Titik Bakar dengan Cleve Land Open Cup, Badan Standardisasi Nasional (BSN) Indonesia, Jakarta, Standar Nasional Indonesia, (SNI) 06-2433-1991, 1991.

[25] G. Sugiyanto, "Kajian Karakteristik Campuran Hot Rolled Asphalt akibat Penambahan Limbah Serbuk Ban Bekas," Jurnal Teknik Sipil, vol. 8, no. 2, pp. 90-103, Feb. 2008.

[26] Directorate General of Highways, Pedoman Perencanaan Campuran Beraspal Panas dengan Pendekatan Kepadatan Mutlak No. 025/T/BM/1999. Jakarta: Direktorat Jenderal Bina Marga, Ministry of Public Works Indonesia, 1999.

[27] G. Perumala and S. Anandan, "Performance evaluation of alkali activated fly ash lightweight aggregates," Engineering Journal, vol. 18, no. 1, pp. 77-85, 2014. doi:10.4186/ej.2014.18.1.77

[28] M. A. G. El Sayed, "Effect of changing theoretical maximum specific gravity on asphalt mixture design," Engineering Journal, vol. 16, no. 4, pp. 137-148, 2012. doi:10.4186/ej.2012.16.4.137

[29] ASTM E102/E102M-93. (2009). Standard Test Method for Saybolt Furol Viscosity of Bituminous Materials at High Temperature. ASTM International, West Conshohocken, PA. [Online]. Available: http://www.astm.org [Accessed: Apr. 15, 2014].

[30] ASTM D6927-06, Standard Test Method for Marshall Stability and Flow of Bituminous Mixtures. West Conshohocken, Pennsylvania: American Society for Testing and Materials, 2006.

[31] Ministry of Public Works Republic of Indonesia. (2006). Pedoman Konstruksi Bangunan No. 00103/BM/2006, Pemanfaatan Asbuton Buku 3 Campuran Beraspal Panas dengan Asbuton Olahan, Jakarta: Ministry of Public Works Indonesia.

[32] G. Sugiyanto, "Marshall test characteristics of asphalt concrete mixture with scrapped tire rubber as a fine aggregate," Jurnal Teknologi (Sciences \& Engineering), vol. 79, no. 2, pp. 55-64, Feb. 2017.

[33] N. Kurniati, "Karakteristik Campuran Beton Aspal dengan Substitusi Ban Bekas sebagai Agregat," Magister Thesis, Civil Engineering: Transportation Engineering, Bandung Institute of Technology, West Java, Indonesia, 2005. Available: http://www.itb.ac.id [Accessed: Apr. 16, 2014].

[34] D. Novianto and U. Subagyo, "Kajian Pengujian Kuat Tarik Tidak Langsung terhadap Campuran Aspal Beton yang Mengandung Serbuk Ban Bekas," Undergraduate Program, Civil Engineering Department, Bandung Institute of Technology, West Java, Indonesia, 2001. Available: http://www.itb.ac.id [Accessed: Apr. 16, 2014.]

[35] G. Sugiyanto, A. Hermawan, and B. Mulyono, "The characteristics of asphalt concrete-binder course (AC-BC) mixture with bottom ash as an aggregate substitute," Civil Engineering Dimension, vol. 17, no. 1, pp. 29-37, Mar. 2015. Available: http://dx.DOI:10.9744

[36] W. Aprina and Silfiani, "Karakteristik Marshall dan Evaluasi Kadar Aspal Optimum Campuran Hot Rolled Sheet dengan Serbuk Ban Bekas sebagai Bahan Tambah," Undergraduate thesis, Civil Engineering Department, Bandung Institute of Technology, West Java, Indonesia, 2005. Available: http: www.itb.ac.id [Accessed: Apr. 16, 2014]. 